\title{
KEMAMPUAN MENULIS NARATIF GURU BAHASA DAN SASTRA INDONESIA DI KABUPATEN BOALEMO: SUATU PENELITIAN AWAL
}

\section{Narrative Writing Ability of Indonesian Language and Literature Teacher in Boalemo Regency: An Initial Study}

\author{
Darmawati M.R \\ Kantor Bahasa Gorontalo \\ Jalan Dokter Zainal Umar Sidiki, Tunggulo, Tilongkabila, Bonebolango \\ darmawati@kemdikbud.go.id
}

\begin{abstract}
Abstrak
Tulisan ini bertujuan mengeksplorasi kemampuan guru-guru bahasa Indonesia di Kabupaten Boalemo dalam hal menulis teks naratif dan deskriptif. Penelitian ini adalah penelitian deskriptif dengan pendekatan kualitatif. Metode yang digunakan dalam pengumpulan data adalah analisis isi. Dari hasil penelitian ditemukan bahwa secara umum, guru-guru bahasa Indonesia di Kabupaten Boalemo telah mampu menulis narasi dengan bahasa Indonesia yang baik dan benar. Hal itu terlihat dari kaidah Pedoman Umum Ejaan Bahasa Indonesia (PUEBI) yang telah diterapkan dengan baik. Akan tetapi, kemampuan tersebut masih harus ditingkatkan dari segi pilihan kata dan ide cerita yang harus lebih variatif.
\end{abstract}

Kata Kunci: literasi, teks, naratif; deskriptif; PUEBI

\begin{abstract}
This paper aims to explore the ability of Indonesian language teachers in Boalemo District in writing narrative and descriptive texts. This research is a descriptive study with a qualitative approach. The method used in the data is the influence of content. From the results of the study found in general, Indonesian language teachers in Boalemo District have been able to write narratives in good and true Indonesian. This can be seen from the rules of the General Indonesian Spelling Guidelines (PUEBI) which have been applied properly. However, this ability must still be improved in terms of words and keywords that must be more varied.
\end{abstract}

Keywords: literacy, text, narrative; descriptive PUEBI

\section{PENDAHULUAN}

Standar Kompetensi Lulusan dalam Kurikulum 2013 berfokus pada kompetensi literasi siswa. Di kelas VII di tingkat sekolah menengah pertama misalnya, siswa diharapkan dapat menguasai kompetensi menulis teks-teks deskripsi, narasi, prosedur, laporan observasi, surat, puisi rakyat, pantun dan syair, serta menceritakan kembali isi fabel, legenda daerah setempat(Peraturan Menteri Pendidikan dan Kebudayaan No.24 Tahun 2016 lampiran 2). Di Kelas VIII, siswa diharapkan mampu menyimpulkan isi berita yang didengar, isi iklan, isi teks eksposisi (artikel ilmiah populer dari koran dan majalah) yang didengar dan dibaca, lalu teks puisi, teks eksplanasi, 
menceritakan kembali si teks ulasan tentang kualitas karya (film, cerpen, puisi, novel, karya seni daerah), juga berbagai hal positif permasalahan aktual dari teks persuasi (yang berhubungan dengan lingkungan hidup, kondisi sosial, dan/atau keragaman, serta menginterpretasi drama baik yang didengar maupun ditonton. Di Kelas IX, siswa SMP diharapkan mampu menganalisis dan memahami, serta mampu menulis kembali teksteks laporan, pidato, cerpen, kritik, teks diskusi dan teks cerita inspiratif.

SKL tersebut tentunya harus diikuti dengan komptensi guru dalam mengajarkan berbagai jenis teks sesuatu tuntutan SKL. Permasalahan yang timbul kemudian adalah bagaimana jika guru-guru bahasa Indonesia tidak mampu menulis teks-teks tersebut dengan baik? Atau yang paling buruk adalah jika guruguru bahasa Indonesia sendiri tidak memahami/menguasai jenis-jenis teks dengan baik.

Kemampuan guru di kelas kita ketahui berpengaruh terhadap performa dan pencapaian siswa di kelas. Telah banyak studi yang dilakukan untuk membuktikan hal tersebut. Seperti yang diungkap Jackson misalnya, bahwa untuk memaksimalkan pembelajaran siswa, guru harus memiliki keahlian dalam berbagai macam kompetensi dalam lingkungan yang sangat kompleks di mana ratusan keputusan penting diperlukan setiap hari (Jackson, 1990). Penelitian Sultan dan Shafi (2014) juga mengungkap bagaimana pengaruh komptensi guru ini berpengaruh pada keberhasilan siswa di kelas.

Kemampuan menulis guru menjadi salah satu faktor yang disorot ketika data statistik UNESCO tahun 2012 menyebutkan indeks minat baca di Indonesia baru mencapai 0,001. Artinya, setiap 1.000 penduduk, hanya satu orang saja yang memiliki minat baca. Hasil penelitian Programme for International Student Assessment (PISA) bahkan menyebut, budaya literasi masyarakat Indonesia pada tahun 2012 terburuk kedua dari 65 negara yang diteliti di dunia. Sementara Vietnam justru menempati urutan ke-20 besar. Pada penelitian yang sama, PISA juga menempatkan posisi membaca siswa Indonesia di urutan ke 57 dari 65 negara yang diteliti. Kenyataan tersebut menempatkan masyarakat kita, secara kultural belum mempunyai budaya literasi yang tinggi. Hal ini adalah fakta yang tidak menggembirakan bagi bangsa yang bercita-cita menjadi negara maju. Rendahnya minta baca tersebut dikait-kaitkan dengan minimnya penugasan membaca dan berkunjung ke perpustakaan terhadap siswa. Ini baru persoalan minat baca. Jika minat baca rendah, dapat kita pastikan bagaimana dengan kemampuan menulis mereka.

Untuk mengatasi hal ini, Badan Pengembangan dan Pembinaan Bahasa, Kementerian Pendidikan dan Kebudayaan turut berpartisipasi dalam Gerakan Literasi Bangsa (GLB) yang dicanangkan oleh Kementerian Pendidikan dan Kebudayaan. Secara garis besarnya, GLB bertujuan menumbuhkan budi 
pekerti anak melalui budaya literasi (membaca dan menulis).

Penerapan Gerakan Literasi Bangsa dalam pengajaran di Tingkat Menengah dilakukan melalui pendekatan sastra. Siswa diharapkan mampu memahami, menganalisis, menanggapi, maupun merekonstruksi dan menulis kembali jenis-jenis teks yang termuat dalam kurikulum, yang menyangkut Kompetensi Dasar dan Kompetensi Inti (KI).

Harapan tersebut sesuai dengan yang termaktub dalam Peraturan Menteri Pendidikan dan Kebudayaan No.24 Tahun 2016 lampiran 2 yang telah disebut di awal pendahuluan ini.

Berdasarkan paparan pada pendahuluan di atas, masalah yang ingin dikaji dalam penelitian ini adalah bagaimana kemampuan menulis narasi guru-guru bahasa Indonesia dan sastra di Kabupaten Boalemo?

Penelitian ini bertujuan mengekplorasi kemampuan menulis narasi guru-guru bahasa Indonesia dan sastra di Kabupaten Boalemo, sehingga hasilnya diharapkan dapat menjadi sumber informasi yang memadai mengenai penggunaan bahasa dalam karangan yang dibuat oleh guru-guru bahasa Indonesia.

\section{TEORI PEMBELAJARAN SASTRA}

Pembelajaran sastra dinilai menantang sekaligus ditakuti bahkan dipandang sebelah mata bagi sebagian pengara bahasa Indonesia. Padahal, salah satu faktor keberhasilan pembelajaran apresiasi sastra di sekolah ditentukan oleh peranan guru yang profesional dalam menangani bidang garapannya (Santosa, 2014). Guru memegang peranan utama dalam mencapai keberhasilan pembelajaran apresiasi sastra di sekolah. Guru pulalah yang harus mampu memotivasi siswanya untuk belajar membaca, mendengarkan, menonton, dan kemudian berbicara, menulis, mencintai, serta menghargai cipta sastra.

Proses pembelajaran apresiasi sastra yang menyenangkan, kreatif, dan inovatif bermula dari kemampuan persiapan seorang guru menyampaikan rencana pembelajaran apresiasi sastra di kelas kepada siswanya, kemudian terjadilah serentetan peristiwa pembelajaran apresiasi sastra yang menyenangkan, kreatif, dan inovatif itu, seperti, (1) pemilihan materi pembelajaran apresiasi sastra, (2) pemilihan metode yang sesuai dengan keadaan siswa, (3) kegiatan belajar mengajar apresiasi sastra yang menyenagkan, kreatif, inovatif, dan (4) evaluasi belajar sebagai indikator keberhasilan pembelajaran apresiasi sastra.

Hal yang menjadi pertanyaan sekarang, dapatkah pengajaran bahasa dan sastra itu berperan untuk membangun SDM yang unggul? Asumsi umum telah menyadari bahwa pengajaran bahasa dan sastra yang baik dapat melahirkan peserta didik yang terampil menggunakan bahasa secara baik sekaligus menghadirkan pengelaman estetik dan mengembangkan kemampuan berbahasa peserta didik. Upaya paling konkret dan terpenting agar peserta didik terampil menggunakanbahasa adalah mendorong siswa untuk gemar membaca. Jika peserta didik sudak suka dan memiliki hobi membaca, mereka akan haus 
bacaan-bacaan (terutama karya sastra) yang bermutu.

Bacaan yang bermutu itu akan memperlihatkan penggunaan bahasayang baik dan kreatif, memberikan cara bernalar yang baik, menyelipkan pesan-pesannilai kehidupan dan mengajarkan keterampilan hidup (life skills) secara halus dan persuatif. Banyak penelitian yang membuktikan bahwa peserta didik yang kemampuan bahasanya tinggi adalah mereka yang banyak membaca. Ada hubungan yang eratantara kebiasaan membaca dengan peningkatan kecerdasan bahasa. (Ganjar,4-5).

\section{Penelitian Terdahulu}

Kemampuan mengarang guru Bahasa Indonesia telah diteliti oleh Nur pada tahun 2017. Penelitian itu bertujuan mendeskripsikan kesalahan berbahasa para guru dalam hal ejaan, diksi, bentuk kata, dan kalimat. Metode yang digunakan adalah metode deskriptif dengan sumber data berupa karangan guru di daerah Lampung Utara. Dari hasil analisis data, teridentifikasi bahwa kesalahan ejaan yang dilakukan guru berupa kesalahan penggunaan tanda baca yang meliputi tanda koma, titik dua, petik, petik tunggal, dan tanda hubung; kesalahan penulisan yang meliputi penulisan huruf kapital, unsur bahasa asing, dan kata berimbuhan. Kesalahan diksi meliputi penggunaan kata tidak baku dan penggunaan kata yang tidak tepat. Kesalahan bentukan kata meliputi bentukan-bentukan kata yang tidak tepat dan tidak sesuai dengan konteks kalimat. Kesalahan kalimat meliputi ketidaksepadanan, yakni ketidakjelasan subjek dan predikat, ketidakhadiran subjek kalimat, ketidakhadiran predikat kalimat, ketidakhadiran objek kalimat, serta kalimat yang hanya memiliki keterangan; penggunaan dua konjungsi intrakalimat di dalam kalimat majemuk bertingkat, penggunaan konjungsi intrakalimat pada awal kalimat tunggal, ketidakhematan, ketidaksejajaran.

Sementara itu, penelitian Sultan dan Shafi pada tahun 2014 lebih mencakup kemampuan guru secara umum, yaitu kaitannya dengan persepsi komptensi guru, lingkungan kelas, preastasi siswa dan hubungan guru dan siswa.

Penelitian mengenai kemampuan menulis guru boleh dikatakan masih terbatas. Pada umumnya, penelitian tentang kemampuan menulis masih berpusat pada kemampuan siswa atau mahasiswa semata, bukan pada guru atau dosennya. Untuk itulah penelitian ini dilakukan. Apalagi mengingat Kabupaten Boalemo masih termasuk area yang jauh dari ibu kota provinsi Gorontalo. Akses guru-guru di daerah ini terhadap informasi masih terbatas. Adanya internet tak cukup membantu karena adanya faktor gagap teknologi di kalangan guru-guru yang telah cukup lama mengajar. Oleh karena itulah penelitian ini diadakan.

\section{SEKILAS MENGENAI KABUPATEN BOALEMO}

Pembentukan daerah otonom di Indonesia seringkali dikaitkan dengan dua hal, yakni bagian dari daerah kerajaan masa lampau dan pembagian daerah menurut aturan kolonial 
Belanda. Berdasarkan data historis, Boalemo pada abad ke-17 pernah menjadi sebuah daerah kerajaan, wilayahnya mencakup bagian barat Gorontalo. Ketika Belanda berkuasa sistem pemerintahan beberapa kali mengalami perubahan. Dalam Lembaran Negara tahun 1925 Nomor 262, Keresidenan Gorontalo dibagi menjadi dua wilayah pemerintahan, yakni; 1) Onder Afdeling Gorontalo dengan Onder distriknya, meliputi Atinggola, Kwandang, Sumalata, Batudaa, Tibawa, Gorontalo, Telaga, Tapa, Kabila, Suwawa dan Bonepantai, 2) Onder Afdeling Boalemo dengan Onder distriknya, meliputi Paguyaman, Tilamuta dan Paguat.

Pada tahun 1946, ketika Sulawesi menjadi bagian dari Negara Indonesia Timur, keswaprajaan yang tertuang dalam UndangUndang Nomor 29 Tahun 1959 perihal pemebentukan Daerah Tingkat II di seluruh Sulawesi. Dalam UU ini Boalemo menjadi salah satu kawedanan dalam wilayah Kabupaten Gorontalo. Status kewedanan Boalemo berlaku sampai dengan keluarnya Undang-Undang Nomor 5 tahun 1974 yang selanjutnya disusul oleh Permendagri Nomor 132 tahun 1978 tentang Pedoman Susunan Organisasi dan Tata Kerja Kantor PembantuBupati/Walikotamadya.

Kemudian bekas Kewedanan Boalemo berubah menjadi Pembantu Bupati Wilayah Kerja Paguat yang meliputi lima kecamatan, yakni; Paguyaman, Tilamuta, Marisa, Popayato. Menengok sejarah Boalemo pada masa lalu, serta mempertimbangkan jarak kendali pemerintahan Kabupaten Gorontalo yang berpusat di Limboto, maka kemudian berkembang aspirasi pembentukan daerah otonom baru. Apalagi saat itu dukungan telah disuarakan oleh Bupati Gorontalo dan DPRD setempat, juga adanya dukungan dari Gubernur dan DPRD Sulawesi Utara sebelum berpisah Gorontalo menjadi provinsi. Kemudian Presiden RI dan DPR RI menetapkan Undang-Undang Nomor 50 Tahun 1999, tanggal 4 Oktober 1999 tentang Pembentukan Kabupaten Boalemo (Lembaran Negara RI tahun 1999 Nomor 178, Tambahan Lembaran Negara RI Nomor 3899).

Kemudian secara resmi Kabupaten Boalemo berdiri setelah diundangkannya pada tanggal 12 Oktober 1999. Pada saat berdiri Kabupaten Boalemo meliputi 5 wilayah kecamatan, yaitu; Kecamatan Paguat, Kecamatan Marisa, Kecamatan Popayato, Kecamatan Paguyaman, Kecamatan Tilamuta, Melihat perkembangan dan dinamika masyarakat Boalemo yang terjadi, serta Provinsi Gorontalo telah terbentuk maka pada tahun 2003 Boalemo dimekarkan lagi. Pada tanggal 27 Januari 2003 Kabupaten Pohuwato berdiri, wilayah ini tadinya merupakan bagian dari Kabupaten Boalemo yang meliputi Kecamatan Paguat, Kecamatan Marisa, Kecamatan Lemito, dan Kecamatan Popayato. Pembentukan Kabupaten Pohuwato sekaligus mengakhiri polemik ditengah masyarakat Kabupaten Boalemo, sebab didalam Pasal 7 UndangUndang Nomor 50 tahun 1999 menyebutkan bahwa Kabupaten Boalemo dalam jangka waktu lima tahun harus memindahkan ibu kotanya dari Tilamuta ke Marisa. 


\section{ASPEK-ASPEK YANG DINILAI}

Berikut aspek-aspek yang dinilai dari teks guruguru SMP se-Kabupaten Boalemo:

\section{Orisinalitas konsep dan struktur cerita.}

Tulisan bahan bacaan harus berisi hal atau ide yang baru dan belum pernah ditulis sebelumnya, bukan plagiat. Jikapun pernah ditulis, sebaiknya mencantumkan sumber referensi yang digunakan.

\section{a. Struktur}

1) Plot atau alur dalam cerita harus sederhana, tidak terlalu rumit untuk dipahami, berurut, berulang, dan mudah untuk ditebak, durasi waktu cerita tidak terlalu lama, mengingat anak memiliki rentang perhatian yang cukup pendek.

2) Tokoh dan penokohan untuk anak seharusnya bersifat rekaan, memiliki kemiripan dengan individu dalam kehidupan yang sesungguhnya, jelas, sederhana, jumlah terbatas, mudah diingat dan dikenal anak.

3) Sudut pandang yang dipilih seharusnya memudahkan anak untuk mengidentifikasi, menginterpretasi, dan memahami cerita dengan bantuan pencerita yang menyampaikan tentang tokoh, peristiwa, tindakan dan motivasi cerita tersebut.

4) Latar cerita untuk anak seharusnya bebas dalam latar apapun, sesuai denagn perkembangan kognitif dan moral anak, latar yang tepat dapat digunakan besok dan sekarang, menghindari rincian waktu agar anak tidak terbebani mengingat detail waktu tersebut, dan tidak dijelaskan secara detail.

b. Nilai Budaya, lokal, moral, sosial, sikap hidup, dan penumbuhan budi pekerti.

1) Dalam cerita anak, selain dihidangkan hal-hal yang menyenangkan, secara langsung atau tidak langsung pembaca anak seharusnya diberikan juga ajaran budaya lokal, moral, sosial, sikap hidup, dan penumbuhan budi pekerti.

2) Membaca cerita merupakan medium yang sangat baik. Di dalam buku bacaan seharusnya berisi hal-hal yang memberi contoh pada anak bagaimanan menyikapi satu permasalahan dengan baik, bagaimana melakukan pembicaraan dengan baik, sekaligus memberi pelajaran dan pembelajaran pada anak bagaimana cara mengendalikan keinginan-keinginan yang dinilai negatif oleh masyarakat.

\section{Kelayakan Bahasa}

\section{a. Ejaan}

Tulisan harus memperhatikan penggunaan ejaan dan tanda baca yaitu;

1) Titik lazimnya dipakai untuk menyatakan akhir dari sebuah tutur atau kalaimat, akhir singkatan, gelar, 
jabatan, pangkat dan singkatan kata atau ungkapan yang sudah lazim. Memisahkan angka ribuaan, jutaan dan seterusnya, juga dipakai untuk meemisahkan angka jam, menit, dan titik,

2) Koma untuk menyatakan perhentian antara (dalam kalimat) memisahkan bagian-bagain kalimat antara kalimat setara yang menyatakan pertentangan, antara anak kalimat dengan induk kalimat, antara anak kaliamat, menandai suatu bentuk parentetis (keterangan-keterangan tambahan yang biasanya ditempatkan dalam kurung), memisahkan anak kalimat dari induk kalimat apabila anak kalimat mendahului induk kalimatnya, atau memisahkan induk kalimat dengan sebuah bagian pengantar yang terletak sebelum induk kalimat, menceraikan kata yang disebut berturut-turtu, dipakai di belakang kata atau ungkapan transisi yang terdapat pada awal kalimat, digunakan untuk menghindari salah baca atau keragu-raguan, untuk menandakan seseorang diajak bicara, (sebelum sapaan), memisahkan aposisi dari kata yang diterangkan, memisahkan kata-kata afektif, memisahkan sebuah ucapan langsung dari bagian kalimat lainnya, memisahkan nama dan alamat, tempat dan tinggal, menceraikan bagian nama yang dibalikkan (untuk referensi misalnya) memisahkan nama keluarga dari gelar akademik, dan menyatakan angka decimal

3) Tanda seru dipakai sesudah ungkapan atau pernyataan berupa seruan atau perintah atau yang menggambarkan kesungguhan atau ketidak percayaaan.

\section{b. Pemanfaaatan bahasa/diksi}

1) Sarana kebahasaan cerita untuk anak harus disesuaikan dengan tahap perkembangan bahasa anak dalam hal kosakata, strutur kalimat sesuai dengan tingkat perolehan bahasa anaka.

2) Kosakata untuk anak seharusnya berisi kata-kata yang mudah, berisi beberpa konsep numeralia dasar, beberapa kata sifat, kata keterangan, kata rujukan orang, preposisi dan kata sambung

3) Kosakata seharusnya tidak bermakna ganda dan tidak konotatif, kata sering diulang-ulang terutama kata yang penting, sederhana, tepat, mudah dicerna dan diingat anak.

4) Struktur kalimat dalam bacaan anak sebaiknya pendek, kadang erisi kalimat negatif, lebih banyak kalimat katif dari pada kalimat pasif, berisi sedikit kalimat majemuk bertingkat, dan berisi kalimat langsung dan literal. 
5) Ragam kalimat yang digunakan seharusnya berbeda-beda. Ada kalimat berita, kalimat tanya, dan kalimat perintah. Adanya ragam kalimat dalam sebuah karangan hanya akan menarik apabila dibandingkan didalamnya hanya kalimat-kalimat ynag itu saja. Barat bicara dengan seseorang, hanya datar dan tidak mempunyai umpan balik sama sekali.

6) Judul seharusnya menggambarkan isi cerita

7) Bahasa yang digunakan tidak bermakna ganda.

\section{PENGERTIAN TEKS}

Teks adalah media atau cara seseorang untuk mengungkapkan sebuah peristiwa secara komunikatif. Teks terbagi menjadi beberapa jenis dan setiap jenis memiliki ciri-ciri, struktur kalimat dan kriteria tertentu yang berbeda antara satu teks dengan yang lainnya. Kriteria teks bersifat objektif menyesuaikan dengan pengamatan seseorang, Untuk membedakan jenis-jenis teks yang pertama dan paling menonjol adalah dengan melihat struktur kalimatnya dan berikut adalah macam-macam jenis teks lengkap dengan pembahasan struktur kalimat dan ciri-cirinya.

\section{JENIS-JENIS TEKS DALAM BAHASA INDONESIA}

Teks dalam Bahasa Indonesia terbagi menjadi 5 jenis teks (Zabadi, 2016). Teks-teks tersebut dijelaskan sebagai berikut.

\section{Teks Narasi}

Teks Narasi adalah jenis teks yang berupa karangan tidak nyata atau fiksi, teks narasi biasanya menceritakan kisah yang sudah memiliki alur dan tahapan waktu berdasarkan keinginan sang penulis. Teks narasi sendiri sangat mudah untuk dikenali karena biasanya berisi cerita-cerita fiksi. Tujuan komunikatif dari teks Narasi adalah sebagai bahan bacaan atau hiburan bagi para pembacanya.

\section{Struktur Teks Narasi:}

Stuktur teks Narasi dapat dibagi menjadi 4 yakni Orientasi, Komplikasi, Resolusi dan Coda.

1. Orientasi: Menggambarkan tentang tokoh dan karakter, latar dan alur dari cerita tersebut.

2. Komplikasi: Berisi tentang pengenalan konflik atau masalah yang terjadi dalam cerita tersebut.

3. Resolusi: Berisi tentang bagaimana akhir atau ending dari cerita. Akhir cerita sendiri dapat dibagi menjadi 2 yakni akhir bahagia dan akhir tidak bahagia.

4. Coda: Coda adalah petuah atau nilainilai moral yang terkandung dalam teks narasi tersebut yang diharapkan dapat diambil hikmahny oleh pembaca.

\section{Teks Deskripsi}

Teks deskripsi adalah teks yang menggambarkan atau memberi penjelasan tentang sebuah obyek entah itu obyek hidup atau mati dari sudut pandang tertentu yang bertujuan agar pembaca dapat merasakan pengalaman seperti dalam teks tersebut. Teks 
deskripsi memiliki tujuan komukatif untuk menyampaikan informasi secara rinci terkait dengan suatu obyek.

\section{Struktur Teks Deskripsi:}

Stuktur teks Deskripsi dibagi menjadi 2 yakni Identifikasi dan Deskripsi

1. Identifikasi: berisi pengenalan secara umum dan menuju ke penjelasan yang lebih terperinci.

2. Deskripsi: berisi penjelasan yang lebih terperinci mengenai obyek yang dibahas dalam teks tersebut. Deskripsi dari obyek tersebut disampaikan melalui beberapa sub kategori. Sebagai contoh saat kita membahas tumbuhan maka akan ada sub kategori seperti jenis tumbuhan, lingkungan hidup dan lain sebagainya.

\section{Teks Prosedur}

Dari namanya tentunya kita sudah bisa menebak jenis teks apakah ini, teks prosedur adalah teks yang berisikan langkah-langkah atau prosedur untuk membuat atau melakukan sesuatu. Teks prosedur umumnya ditemui dalam bentuk tutorial seperti resep masakan, panduan membuat kerajinan tangan dan masih banyak lagi. Tujuan dari teks prosedur adalah untuk memberikan petunjuk secara terperinci kepada pembaca tentang bagaimana cara melakukan atau membuat sesuatu.

\section{Struktur Teks Prosedur:}

Stuktur teks prosedur dapat dibagi menjadi 3 yakni Tujuan, Bahan dan langkah.

1. Tujuan: berisi tentang tujuan dari suatu kegiatan. Teks prosedur biasanya langsung dapat dikenali hanya dengan melihat judulnya saja, seperti contoh: Cara membuat..., Cara menjalankan..,

2. Bahan: berisi tentang Bahan dan alat yang diperlukan dalam kegiatan.

3. Langkah: berisi tentang langkah atau panduan melakukan sesuatu.

\section{Teks Laporan}

Teks laporan adalah teks yang berisi tentang informasi atau laporan secara umum suatu obyek. Pembahasan yang dilakukan dalam teks laporan biasanya hanya secara umum atau berdasarkan pengamatan sepintas saja. Tujuan dari teks laporan sendiri adalah untuk menyampaikan suatu informasi secara umum kepada pembaca.

\section{Struktur Teks laporan:}

Stuktur teks laporan dibagi menjadi 2 yakni Klasifikasi umum dan deskripsi.

1. Klasifikasi umum: berisi tentang pengelompokan informasi secara umum.

2. Deskripsi: berisi tentang penjelasan informasi utama yang sudah dipilah menjadi beberapa sub kategori informasi yang tetap disampaikan secara umum.

\section{Teks Eksposisi}

Teks eksposisi adalah teks yang berbentuk karangan yang bersifat memaparkan kejadian atau informasi dan pengetahuan secara singkat, padat dan akurat. Teks eksposisi bersifat ilmiah atau non fiksi. Tujuan dari teks eksposisi sendiri adalah untuk memaparkan suatu kejadian atau informasi kepada pembaca sejelas-jelasnya. 


\section{Struktur Teks Eksposisi:}

Struktur teks eksposisi terdiri dari tesis, argumen dan penegasan.

1. Tesis: Tesis adalah pembukaan atau pengenalan dari suatu informasi didalam teks

2. Argumentasi: adalah pokok bahasan yang dipaparkan.

3. Penegasan: Penegasan pokok-pokok bahasan yang menguatkan pemaparan dari informasi tersebut.

\section{PEDOMAN UMUM EJAAN BAHASA INDONEDIA (PUEBI)}

Pedoman Umum Ejaan Bahasa Indonesia (PUEBI) telah diterbitkan oleh Badan Pengembangan dan Pembinaan Bahasa pada tahun 2015. PUEBI penyempurnaan dari Ejaan Bahasa Indonesia yang Disempurnakan atau EYD. Perubahan tersebut juga diperkuat dengan dieluarkannya Peraturan Menteri dan Kebudayaan (Permendikbud) RI Nomor 50 Tahun 2015 tentang Pedoman Umum Ejaan Bahasa Indonesia.

Perubahan tersebut dilatar belakangi oleh beberpaa hal, yaitu 1) dampak kemajuan ilmu pengetahuan, teknologi, dan seni yang telah menyebabkan penggunaan bahasa Indonesia dalam berbagai ranah pemakaian, baik secara tulis maupun tulisan, menjadi semakin luas, hal yang membuat diperlukannya perubahan pada ejaan bahasa Indonesia; 2) perlunya menyempurnakan kaidah mengenai ejaan Bahasa Indonesia untuk memantapkan fungsi bahasa Indonesia sebagai bahasa negara dan sebagai piranti penting untuk mempersatukan bangsa.

\section{METODE}

Penelitian ini merupakan penelitian deskriptif dengan pendekatan kualitatif. Teknik analisis data dilakuakn dengan analisis isi. Penelitian dilakukan dengan menempuh langkah-langkah berikut: (1) menentukan masalah dan objek penelitian; (2) melakukan studi pustaka berkaitan dengan penelitian, dan (3) melakukan proses analisis berdasarkan kerangka teori yang telah ditetapkan.

Sumber data dalam penelitian ini adalah karangan guru SMP Kab-Boalemo tahun 2018.

\section{TEMUAN DAN HASIL PEMBAHASAN}

Ada 53 Sekolah Menengah Pertama di Kabupaten Boalemo. Dalam kajian ini, di ambil 12 karangan guru dari 12 sekolah.

\section{Sedapnya Milu Siram Buatan Mama oleh Raharjo Ismail}

Teks narasi yang dibuat Raharjo Ismail ini sudah dapat dijadikan bahan bacaan yang representatif. Originalitas tinggi, buku ditampilkan dengan kreatif, dan menarik. Ilustrasi juga proporsional dengan teks. Nilai yang disampaikan penulis adalah membuat anak-anak lebih dekat dengan makanan khas Gorontalo, yaitu Milu Siram, misalnya dengan menggunakan kata-kata, aroma yang harum, lalu ada dialog menggunakan logat Melayu Manado yang kental, "Sadap skali milu siram ti mama bikin ini am, bo rasa-rasatambah 
(Sedapnya milu siram buatan mama ini, rasanya mau tambah terus).

Selain itu, nilai yang disampaikan adalah jangan menembaki burung, meskipun itu burung pengganggu, lebih baik hanya mengusirnya, karena sesama mahluk Tuhan kita harus saling mengasihi.Hal ini terkandung dalam dialog Ayuba dan Sunu, nama tokohnya. Sunu mengomentari Ayuba untuk tidak menmbaki burung ketika Ayuba mengeluh lupa membaca ketapel.

Selain itu ada tokoh Paman Hamu yang memperingatkan mereka untuk memetik jagung sesuai keperluan, misalnya untuk membuat milu siram, hanya jagung muda yang diperlukan. Juga ada nilai moral untuk saling membantu seperti pada kalimat berikut.

"Ayuba dan Sunu tergopoh-gopoh memikul jagung dalam karung. Mereka saling bergantian memikulnya."

Kekurangan karya Raharjo Ismail ini terletak pada ejaan yang belum rapi, seperti penggunaan koma sebelum sapaan, dan setelah keterangan waktu di awal kalimat. Penggunaan preposisi di- dan awalan di- sudah baik. Demikian halnya penulisan bahasa daerah dalam dialog maupun narasi di buku sudah ditulis miring.

Dari segi diksi, pilihan kata yang digunakan sudah mampu menarik minat baca anak-anak. Misalnya Minggu yang cerah, hamparan tanaman jagung terlihat indah. Daun-daun hijau yang menghiasi buah jagung yang terseli di beberapa batang dan daun, untain kata-kata ini sangat mampu membangkitkan imajinasi pembaca seoleh mereka berada di ladang jagung.

\section{Bolalo Lo Limutu oleh Dewi Ibrahim, $\mathbf{S}$.}

Pd.

Teks cerita rakyat yang ditulis kembali oleh Dewi Ibrahim ini masih tidak rapi dari segi ejaan, penulisan kata/bahasa daerah belum ditulis miring, si penulis belum teliti dalam menata letak tulisannya, tidak ada spasi setelah tanda baca titik, juga tanda baca lainnya. Si penulis juga belum bisa membedakan penulisan awalan di- dengan di- sebagai preposisi. Penggunaan huruf kapital di awal kalimat juga belum maksimal. Tidak ada nilai moral yang dapat dipetik dari cerita asal mula danau Limboto versi Dewi Ibrahim ini. Sebaiknya lebih dieksplorasi dan dikembangkan agar menjadi bahan bacaan yang menarik.

\section{Pesona Tradisi Walima di Desa Bubohu oleh Mike Abdurrahman, S.Pd.}

Teks yang dibuat oleh Mike Abdurrahman ini sudah baik, sayangnya, penggunaan ejaan sangat tidak rapi. Ketidaktrapian itu menyangkut penulisn huruf kapital, penulisan tanda baca titik dan koma, penulisan bahasa daerah.

Akan tetapi, tulisan Mike ini tetap menarik dan mengundang keingintahuan pembaca untuk menyaksikan acara Walima di Desa Bubohu, sebagaimana yang tertera pada judul tulisan. Ilustrasi yang digunakan di akhir tulisan lumayan menambah keingintahuan itu.

Diksi yang digunakan Mike sudah lumayan baik, misal kata;kata berikut.

"Selain menyaksikan tradisi walima di desa Bubohu, para wisatawan dapat menikmati 
taman wisata pesantren alam Bubuhu yang dirimbuni pepohonan dengan dua kolam santri dan kolam asma'ul husna, ratusan fosil kayu yang tertata rapi sebagai museum..." walima...”

"Emas yang kubahnya berbentuk

Ada beberapa kata lokal yang bisa dikembangkan misalnya kata dikili, kolombengi, toyopo, dan tolangga.

\section{Menyambut Malam Bakupas oleh Sitti}

\section{Mayana, S. Pd.}

Teks narasi ini terlalu pendek, font yang digunakan cukup besar untuk ukuran anak SMP. Penulisan bahasa daerah belum ditulis miring, demikian halnya dengan penggunaan huruf kapita, tanda baca titik, dan koma. Tulisan ini bisa memantik rasa ingin tahu apa bila diolah dengan lebih serius dan teliti. Nilai moral belum dieksplorasi kecuali nilai budaya. Cara bertutur juga masih agak kaku.

\section{Ada Ilmu di Bubur Sada oleh Salwiyah}

\section{Dai, S. Pd.}

Tulisan ini memuat nilai-nilai persahabatan, juga kebijaksanaan. Diksi yang digunakan sudah baik, ejaan sudah rapi, hanya saja ada penulisan kata yang cenderung berulang sehingga memungkinkan menimbulkan kebosanan, misalnya, "Lelaki ini adalah teman dari empat sahabat tadi."

Penggunaan diksi lelaki, bisa diganti dnegan anak laki-laki. Kemudian penggunaan tanda petik dua untuk pembuka dan penutup dialog belum digunakan secara tepat. Misalnya

"teman-teman, bubur sada yang kita makan tadi enak ya".
Tanda titik ditulis sebelum tanda petik dua yang menutup dialog. Dialog juga dimulai dengan huruf kapital.

Nilai moral yang coba disampaikan penulis adalah sebagai masyarakat Gorontalo, mereka (tokoh) harus bangga dengan kebudayaan kuliner yang mereka miliki, Bahasa yang digunakan selain kata'lelaki" tadi sudah layak.

\section{Binte Biluhuta oleh Febrian Novita Kiay}

\section{S. Pd.}

Teks narasi yang dibuat oleh guru SMPIT Al Izzah ini menggunakan alur yang runtut, bahasa yang apik dengan pilihan kata yang sepertinya diperhitungkan dengan baik. Sayang sekali, penulis belum teliti dalam menggunakan/menulis ejaan, terutama penulisan huruf kapital untuk nama jenis. Febrian menyajikan versi milu siram yang menggugah selera pembaca. Varian campuran yang digunakan dalam milu siram seperti udang atau daging, sesuai selera penikmatnya, memberi informasi yang padat yang memang ada dalam sebuah teks daskripsi.

Selain itu, Febrian mengungkap nilai manfaat menyantap Milu Siram yang dapat menurunkan kadar kolesterol jahat dalam darah. Menyantap m Milu Siram juga baik untuk ibu hamil.

\section{Andai Masa Itu Terulang Pada Anak}

Kita oleh Yanti Kadir Ulliloto, S. Pd.

Karya Yanti Kadir yang satu ini sebenarnya dapat dijadikan bahan bacaan untuk anak SMP. Nilai budaya dan nilai moralnya ada (mempertahankan permainan tradisional 
Gorontalo). Selain itu banyak informasi yang berguna mengenai permainan khas daerah Gorontalo. Bahasa yang digunakan juga sudah cukup baik. Hanya saja, kalimat yang digunakan terlalu panjang. Misalnya pada paragraf pertama:

“..Untuk tahap selanjutnya dilanjutkan oleh teman-temanku yang tinggi dan biasanya aku tidak betah bermain lompat goro apalagi dengan tim yang tinggi selain melelahkan aku tidak adapat bermain sepenuhnya."

Kalimat yang termuat dalam satu parangraf terlalu banyak (memuat 23 kalimat). Penulisan bahasa daerah yang belum ditulis miring. Dalam bacaan ini terlalu banyak kata aku, hal yang biasa disebut 'serangan aku' dalam menulis teks narasi atau cerita pendek.

Selain itu penulisan kata alarm, gadget belum tepat (ditulis alarm, gedjet)

\section{Proses Ritual Naik Rumah Baru oleh Nur Afni Ismail, S.Pd.}

Teks yang ditulis oleh Nur Afni Ismail ini tidak menambah informasi yang berarti. Penulis hanya mengungkapkan persiapan naik rumah baru yang meliputi hal-hal berikut.

a. Mencari tanggal, hari dan bulan yang baik untuk naik rumah baru.

b. Mengundang orang tua, imam, atau ustadz yang dipercayai untuk membacakan doa.

c. Buah pisang 1 tandang.

d. Kacang kulit.

e. Alat-alat dapur, seperti: cukuran, loyang, peda, gergaji, dan alat dapur lainnya.
Lalu ada pelaksanaan ritual itu. Akan lebih bagus jika Nur Afni mampu menjelaskan makna di balik satu tandan pisang, kacang kulit, alat-alat daput seperti logang, peda, gergaji dan alat daput lainnya sehingga menambah nilai budaya pada tulisan ini.

Terdapat penggunaan kata yang agak boros, misalnya kata harus wajib, untuk kemudian, bermacam-macam alat-alat dan banyak katakata yang berulang-ulang.

\section{Puade Lo Tangga 2000 oleh Andriani Daud.}

Untuk gaya bertutur, karya Andriani Daud ini sudah baik. Sayangnya, bahasa yang digunakan lebih tepat atau cocok untuk kalangan mahasiswa, bukan anak-anak SMP. Narasi yang berbentuk cerita pendek ini belum bisa disajikan pada anak-anak usia sekolah menengah pertama. Padahal, unsur budaya yang termuat dalam cerpen ini kaya akan kekhasan daerah Gorontalo (pengenalan kata uti, dan nou, misalnya).

Pilihan kata yang digunakan sudah bervariasi, misalnya:

"Rembulan ketika itu, tak menampakkan wajahnya."

Andriani Daud sudah lumayan baik dalam penulisan huruf kapital, penggunaan tanda baca titik dan koma, hanya saja penulisan preposisi di- dan awalan di- masih sering bertukar-tukar.

\section{Tentang Nidna dan Soko oleh Siti R.}

\section{Mahmuda}

Karya Siti R Mahmuda ini juga dipenuhi oleh 'serangan aku' sehingga tidak terlalu renyah dibaca, namun sudah lebih baik dalam 
penulisan ejaan, mislanya menulis miring kata bahasa daerah. Tulisan ini mencoba mengenalkan makanan soko, sejenis makanan yang terbuat dari singkong yang cincangcincang atau diparut dalam parutan khusus, untuk diperas airnya dan dimasak bersama beras. Ada informasi tambahan mengenai miripnya soko ini dengan nasi tiwul, daerah asal penulis.

\section{Ada Gelisah di Pilitode Ayam oleh Lena}

\section{Lapasau, S. Pd.}

Tulisan Lena Lapasau yang berupa cerpen ini lebih cocok untuk mahasiswa, bukan anakanak SMP.

Misal kata-kata berikut.

"Keesokan hari, kurangkul dia, aku harus memberinya semangat agar kebimbangan tidak merasuk dan mengguncang hati dalam ketidakpastian."

Rangkaian kata ini masih belum mudah dipahami oleh anak SMP.

Penggunaan tanda baca koma juga belum tepat (koma sebelum sapaan tidak digunakan). Misalnya pada kalimat berikut.

"Tok...tok...tok, Mutia buka pintunya sayang, mama ingin curhat nak,"....

Seharusnya:

Tok...tok...tok, Mutia buka pintunya, Sayang. Mama ingin curhat, Nak,"....

Dalam aspek lain, ejaan juga belum rapi.

\section{Kue Onde-Onde Di Kampung Nenek} oleh Sumitro Ulitoto, S.Pd.

Teks narasi yang dibuat oleh Sumitro ini ditulis dengan ejaan yang rapi. Cara bertuturnya renyah sehingga mampu menarik minat baca dan keingintahuan pembaca. Pilihan kata juga runtut, kalimat-kalimatnya koheren, dan tidak panjang-pannjang. Bahasa daerah telah ditulis miring.

Nilai moral yang ada dalam cerita ini adalah bangga akan kuliner khas daerah Gorontalo. Si tokoh juga memasukkan unsur kekinian di mana remaja gemar memfoto kegiatan-kegiatannya sehari-hari dan menaruhnya di laman media sosial sehingga dikomentari oleh netizen yang lain.

Kedua belas teks karangan guru-guru Bahasa Indonesia di Kabupaten Boalemo dapat dilihat bahwa mereka telah mampu menggunakan bahasa dengan baik, tingkat apresiasi sastra masih terbilang rendah, penggunaan ejaan yang belum taat azas dan belum sesuai dengan Pedoman Umum Ejaan Bahasa Indonesia. Pilihan kata sudah baik, demikian halnya dalam memilih ide cerita.

\section{PENUTUP}

\section{Simpulan}

Kedua belas teks karangan guru-guru Bahasa Indonesia di Kabupaten Boalemo dapat dilihat bahwa mereka telah mampu menggunakan bahasa Indonesia sesuai Pedoman Umum Ejaan Bahasa Indonesia dengan baik. Akan tetapi, dari segi pemilihan kata dan ide cerita masih perlu ditingkatkan. 


\section{Saran}

Pelatihan kepenulisan sebaiknya lebih sering diadakan untuk kalangan guru untuk mengasah keterampilan mereka dalam menulis.

\section{DAFTAR PUSTAKA}

Amadi, Mukhsin. 1990. Strategi Belajar Mengajar Keterampilan Berbahasa dan Apresiasi Sastra. Malang: YA3 Esten.

Tim Pengembang Pedoman Bahasa Indonesia. 2016. Pedoman Umum Ejaan Bahasa Indonesia. Jakarta: Badan Pengembangan dan Pembinaan Bahasa. Kementerian Pendidikan dan Kebudayaan.

Jackson, P. W. (1990). Life in classrooms. New York, NY: Teachers College Press.

Mursal. 1992. Apresiasi Sastra. Padang: Angkasa.

Nur, Kiki Zakiah. 2017.'Kesalahan Berbahasa pada Karangan Guru Bahasa Indonesia SMP Se-Lampung Utara" dalam Jurnal Imiah Kebahasaan dan Kesastraan Telaga Bahasa, Volume V Nomor 2, Edisi Desember 2017, Halaman 261-278

Oemarjati, Boen S. 1992. Dengan Sastra Mencerdaskan Siswa, Memperkaya Pengalaman dan Pengetahuan. Jakarta: Pustaka Sinar Harapan.

Harimansyah, Ganjar. 2012. Pengajaran Bahasa dan Sastra (Sumbang Saran untuk Mengurai Problem Pengajaran Bahasa dan Sastra) dalam STILISTIKA Vol 1, No 1 Tahun 2012.

Rusyana, Yus. 1984. Metode Pengajaran Sastra. Yogyakarta: Kanisius.

Santosa, Puji. dan Djamari. 2014. Apresiasi Sastra Disertai Ulasan Karya, Proses Kreatif, dan Riwayat Sastrawan. Yogyakarta: Elmaterra.

Sultan Sarwat dan Shafi, Muhammad.2014.

"Impact of Perceived Teachers's
Competence on Student's Perfomance: Evidence for Mediating/Moderating Role of Class. "dalam i-manager's Journal on Educational Psychology, Vol. 81 No. 11 May - July 2014.

Sumarjo, Yakob dan Saini K.M. 1986. Apresiasi Kesusastraan. Jakarta: PT Gramedia.

Sumardi, Muljanto (ed). 1992. Berbagai Pendekatan dalam Pengajaran Bahasa dan Sastra. Jakarta: Pustaka Sinar Harapan.

Teeuw.A. 1984. Sastra dan Ilmus Sastra, Pengantar Teori Sastra. Jakarta: Pustaka Jaya.

Trotsky, Leon (1923). Akar dan Fungsi Sosial Dunia Sastra ( The Social Roots and the Social Function of Literature) Trotsky Internet Archive Penerjemah: Dewey Setiawan (April 2003) http://www.marxists.org/, diakses 9 Juli 2017.

Wiarsih, Cici. 2013.Keefektivan Media Komik dalam Peningkatan KemampuanBerpikir Kreatif danKemampuan Mengapresiasi Drama.

Zabadi, Fairul. 2016. "Pemahaman berbagai Jenis-Jenis Teks. " Disampaikan pada Pelatihan Instruktur Nasional di Hotel Mirah, Bogor. 
Telaga Bahasa, Vol. 6, No. 2, Juni 2018: 405-420 